\title{
DECONSTRUCTING SECTION 11: PUBLIC OFFERING LIABILITY IN A CONTINUOUS DISCLOSURE ENVIRONMENT
}

\author{
DONALD C. LANGEVOORT*
}

INTRODUCTION

Shortly after the Securities Act of $1933^{1}$ ("1933 Act") became law, critics from the securities industry charged that the civil liability provisions created by Section 11 of the Act made it excessively draconian. Mandatory disclosure and prospectus delivery, even pre-clearance by a federal agency, were troublesome enough. However, strict liability to investors for issuers, and failure of "due diligence" liability for underwriters, accountants, officers, and directors for material misstatements in a registration statement, were quite another mattermaking Section 11 the "bete noire," in Louis Loss's words, of the legislative scheme. ${ }^{2}$ Opponents ominously warned that the legislation would dry up American capital-raising. ${ }^{3}$ Even though they were eventually proven wrong in that particular prediction, ${ }^{4}$ the industry was right to see the threat of private civil liability as the engine that drives the 1933 Act. ${ }^{5}$ Estimates in the finance literature suggest, for example, that a sizable portion of the underwriters'

Copyright (C) 2000 by Donald C. Langevoort

This article is also available at http://www.law.duke.edu/journals/63LCPLangevoort.

* Professor of Law, Georgetown University Law Center.

The author would like to thank the participants at the Park Hyatt Conference for their helpful thoughts and criticisms.

1. Securities Act of 1933, Pub. L. No. 73-22, 48 Stat. 74 (codified as amended at 15 U.S.C. $\S \S 77$ a77aa (1994)).

2. Louis Loss \& JOEL SEligman, SECURIties REgulation 4246 (3d ed. 1991).

3. See id.; see also Joel Seligman, The Transformation OF WAll StreEt 77 (2d ed. 1995). Admittedly, Section 11 was revised in 1934 to take account of some of the concerns, but these changes did not alter the basic thrust of the liability scheme.

4. The prediction failed even when Section 11 was eventually given a broad reading in the 1960s. See Escott v. Barchris Const. Co., 283 F. Supp. 643, 697 (S.D.N.Y. 1968).

5. For a seminal study on the law and economics of Section 11, see Michael Dooley, The Effects of Liability on Investment Banking and the New Issues Market, 58 VA. L. REV. 776 (1972). 
spread is a liability risk premium, ${ }^{6}$ and lawyer-disseminated fear of liability casts a harsh shadow over the due diligence process.

In the late 1970s and early 1980s, concerns about the relationship between liability and capital-raising efficacy reappeared. Large, seasoned issuers were moving significant capital-raising transactions offshore, into the so-called Eurodollar market. Delays associated with the Securities and Exchange Commission ("SEC") review and limits on publicity and marketing of domestic offerings were blamed. In response, the SEC introduced "short-form" registration for large capitalization issuers via Form S-3 and modernized and expanded the availability of shelf registration, thereby permitting large issuers to move quickly to take advantage of market opportunities without excessive regulatory delays. ${ }^{8}$ In the political process and in academic debates, however, the principal risk associated with speeding up the distribution process was readily identified. Disclosure quality is threatened by the de facto loss of opportunity for external due diligence by underwriters and others associated with the issuance from the time the decision to sell is made to the time securities are purchased by investors.' Underwriters thus found themselves in a world of de jure liability if there were misstatements or omissions; only a vague Commission rule, coupled with some informal suggestions for ex ante "continuous due diligence" as protection, seemed to suggest a more permissive standard of due diligence in such settings. ${ }^{10}$

Today, few suggest that we should, or can, backtrack on liberalization of the 1933 Act. ${ }^{11}$ Instead, regulatory efforts all point to the opposite: further expansion of the speed and limited disclosure responsibilities associated with large company capital-raising. ${ }^{12}$ Yet, this simply focuses all the more attention on li-

6. See, e.g., Seha M. Tinic, Anatomy of Initial Public Offerings of Common Stock, 43 J. FIN. 789, 791 (1988). Whether this can be offered as an explanation for the "underpricing" of IPO's is a separate question. See Janet C. Alexander, The Lawsuit Avoidance Theory of Why Initial Public Offerings Are Underpriced, 41 UCLA L. REV. 17, 19 (1993).

7. This is not to say that some of that fear is not somewhat overstated. See Donald C. Langevoort \& Robert K. Rasmussen, Skewing the Results: The Role of Lawyers in Transmitting Legal Rules, 5 S. CAL. INTERDISC. L.J. 375, 437 (1997); Louis Loss, The Opinion, 24 BUS. LAW. 527, 530 (1969).

8. For a good discussion of this history, see Edward Greene, Determining the Responsibilities of Underwriters Distributing Securities Within an Integrated Disclosure System, 56 NOTRE DAME L. REV. 755 (1981).

9. See generally Barbara Ann Banoff, Regulatory Subsidies, Efficient Markets, and Shelf Registration: An Analysis of Rule 415, 70 VA. L. REV. 135 (1984); Merritt B. Fox, Shelf Registration, Integrated Disclosure and Underwriter Due Diligence: An Economic Analysis, 70 VA. L. REV. 1005 (1984); Greene, supra note 8.

10. 17 C.F.R. $§ 230.176$ (2000); see also JAMES D. COX ET AL., SECURITIES REgulation: CASES AND MATERIALS 620 (2d ed. 1997).

11. In fact, there are some who would, in the abstract, like to restore the lost discipline. See, e.g., Merritt Fox, Rethinking Disclosure Liability in the Modern Era, 75 WASH. U. L.Q. 903, 912 (1997). But even here, recognition that liability can easily move capital-raising offshore leads scholars like Professor Fox to call for alternatives rather than restoration. See text accompanying notes 89-91 infra.

12. The so-called "Aircraft Carrier" SEC rule proposals on reforming the public offering process generally express support for a continuation of broad Section 11 liability. See Securities Act Release No. 7606A, 63 Fed. Reg. 67,174 (Dec. 4, 1998) [hereinafter Aircraft Carrier]. The company registration idea derives from the report of the Commission's Advisory Committee on Capital Formation and the Regulatory Process, which did not recommend Section 11 reforms either. See SEC REP. OF THE AdVISORY COMMITTEE ON THE CAP. FORMATION \& REG. PROCESSES 33 (July 24, 1996), reprinted in 
ability, and to this point, the Commission has suggested only minimal reform: clarifying the due diligence responsibilities associated with short-form offerings to take account of "practicability" concerns. Indeed, to the consternation of many, the Commission suggested expanding the kinds of issuer-generated information that would otherwise be subject to negligence-based civil liability under the 1933 Act. $^{13}$

This article is an effort to rethink civil liability in capital-raising transactions by large capitalization issuers. ${ }^{14}$ After a brief digression about who should set liability standards, the article then addresses two related questions. The first deals with a natural question: Should not the primary regulatory effort for large issuers be to assure continuous disclosure in the secondary marketplace, given the far larger volume of such trading in that market compared to that in primary transactions $?^{15}$ Second, if we have developed a satisfactory regime of disclosure responsibilities for this setting, what more, if anything, in terms of liability protection, is needed when such issuers sell new stock into an existing market for their securities?

My conclusions on the first question come in a discrete series of recommendations. I think that the existing system is largely satisfactory as a conceptual matter, although public resources for enforcing that regime are woefully lacking; I would not significantly expand private rights of action for continuous disclosure transgressions. I would, however, create a much more determinate obligation on the part of seasoned issuers to implement an efficient disclosure monitoring system, an elaboration of the current obligation to have a reasonable system of internal accounting controls found in Section 13(b)(2)(B) of the Securities Exchange Act ("1934 Act"). As a "carrot" to induce compliance, I would reduce the fraud-on-the-market exposure for issuers who demonstrate that such a system was in place and functioning.

Having made minor reforms to the 1934 Act liability structure, I would then deconstruct Section 11 as applied to larger issuers. The effect of this proposal would be to retain a regime of negligence-based liability for insiders in connection with public offerings, but to substitute a scienter-based liability regime un-

[1996-1997 Transfer Binder] Fed. Sec. L. Rep. (CCH) II 85,834 [hereinafter Wallman Commission Report]. However, concurring and dissenting members of that Committee took pains to point out that absent Section 11 reforms, much of the effort to modernize the regulatory process will be thwarted. For a survey of the relationship between process and liability reform issues by one of those dissenters, see John C. Coffee, Jr., Re-Engineering Corporate Disclosure: The Coming Debate Over Company Registration, 52 WASH. \& LEE L. REV. 1143 (1995).

13. See, e.g., Richard H. Rowe, The SEC's Aircraft Carrier Proposals, 32 REV. SEC. \& COMMOD. REG. 65 (1999). There would be a mild expansion of Section 11 exposure. The real threat would come via Section 12(a)(1) - a negligence-based standard for liability. The Aircraft Carrier would require the filing of much free-writing "sales" material and make it explicitly subject to this liability provision. See id.

14. Although it is a very important issue, I will not focus on the definition of "large capitalization issuer." By all accounts, the definition should turn on identifying those companies with sufficient investor interest and analyst following that the properties associated with marketplace efficiency attach.

15. This is simply an elaboration on the classic question posed by Milton Cohen in his seminal article on the structure of securities regulation. See Milton Cohen, "Truth in Securities" Revisited, 79 HARV. L. REV. 1340, 1341-42 (1966). 
der Rule 10b-5 for others associated with the offering. The article ends by asking whether, drawing from what we have concluded, other 1933 Act liability reforms are appropriate.

\section{II}

\section{DIGRESSION: WHO SHOULD SET THE STANDARDS?}

Before turning to the substance of reform, we should consider seriously what many scholars are recommending as a threshold jurisdictional matter: eliminating exclusive federal jurisdiction over capital-raising disclosure standards and enforcement. Various proposals have been advanced. One is to assign such responsibility to a securities exchange for listed companies or exchange-equivalent, so that the exchange would define both the substance of required disclosure and the sanctions for violations. ${ }^{16}$ Another is to give the same power to the various states in the United States, or to foreign countries. ${ }^{17}$ With more or less freedom, issuers could opt in to whatever locus of jurisdiction they choose, so long as the choice was made known to investors in advance of the offering. Another related possibility would be to allow the SEC to retain its role as a "form-giver" and enforcer, but then to permit companies a large amount of freedom to opt out of federal mandatory disclosure responsibilities. This would put the SEC into competition with other potential form-givers, public and private, though preserving the Commission's role with respect to actual fraud. $^{18}$

All of these proposals work from essentially the same premise. Exclusive federal disclosure and enforcement standard-setting, whether through legislation or rule-making, risks either politicization or law-making incompetence. The effect of setting the standards too high is to weigh down the capital formation process except for those issuers that can easily engage in regulatory arbitrage by going outside of the United States to raise money. In contrast, a system of regulatory decentralization coupled with freedom of choice breeds competition among regulators. By hypothesis, issuers will choose the exchange or state that offers the most efficient system of law. Investors demand a reasonable degree of protection and will pay less for securities issued by companies that choose an inferior exchange or state. Hence, exchanges or states will work hard; after all, it is in their economic self-interest to develop optimal systems of

16. See Paul G. Mahoney, The Exchange as Regulator, 83 VA. L. REV. 1453, 1498-99 (1997) [hereinafter Mahoney, Exchange as Regulator]; Adam Pritchard, Markets as Monitors: A Proposal to Replace Class Actions with Exchanges as Securities Fraud Enforcers, 85 VA. L. REV. 925 (1999).

17. See Stephen I. Choi \& Andrew T. Guzman, Portable Reciprocity: Rethinking the International Reach of Securities Regulation, 71 S. CAL. L. REV. 903, 950 (1998); Roberta Romano, Empowering Investors: A Market Approach to Securities Regulation, 107 YALE L.J. 2359, 2362 (1998).

18. See Alan R. Palmiter, Toward Disclosure Choice in Securities Offerings, 1999 COLUM. Bus. L. REV. 1, 96-97. 
regulation, ${ }^{19}$ and capital will migrate to those jurisdictions that appear to the market to be most successful in that venture, providing effective feedback.

To be sure, there is a theoretical appeal to this sort of structure. It resembles the "race to the top" argument in state corporation law. While that argument has rightly been criticized as inapplicable to firms that are not dependent on the capital markets for funds and relatively insulated from the threat of hostile takeovers ${ }^{20}$ the proposals here are not immediately subject to the same critique. Here, we are talking only about the legal regime that applies to the capital-raising transaction of a particular firm, which, by definition, is marketsensitive. Jurisdictions would develop reputations within investor communities, which would be tarnished to the extent that scandals subsequently emerged and were not remedied.

This literature has generated substantial debate ${ }^{21}$ which I do not want to revisit comprehensively. A threshold issue, of course, is whether the market would rationally "price" competing legal regimes." At the very least, there must be differentiation between widely-followed stocks and initial offerings or those that trade in thinner markets. All I wish to do here is to make a narrower set of points that I do not think have received enough emphasis in the debate. As to the capacity of the exchanges, the main point made by commentators is whether the exchanges' lack of legal adjudicatory capacity would undermine the efficacy of any standards that they create..$^{23}$ I share that doubt, but also fear the exchange as a standard-setter or enforcer given the conflicting interests of its member-owners. To the extent that multi-service securities firms have significant political influence at the exchanges, there is considerable tension in their preferences. While they seemingly have the interest in promoting issuer candor

19. For exchanges, the economic incentive of listings is obvious. States also benefit, both directly in the form of fees and by channeling a good bit of business to local providers of professional services (including lawyers, investment bankers, and accountants).

20. See Lucian Arye Bebchuk, Limiting Contractual Freedom in Corporate Law: The Desirable Constraints on Charter Amendments, 102 HARV. L. REV. 1820 (1989).

21. For more critical perspectives on the "freedom of choice" regime, see James D. Cox, Regulatory Duopoly in the U.S. Securities Markets, 99 ColuM. L. REV. 1200 (1999); Merritt A. Fox, Securities Disclosure in a Globalizing Market: Who Should Regulate Whom?, 95 MICH. L. REV. 2498 (1997); Edmund Kitch, Competition Between Securities Markets: Good or Bad?, in THE FUTURE FOR THE GLOBAL SECURITIES MARKETS: LEGAL AND REGULATORY ASPECTS 233 (Fidelis Oditah ed., 1996).

22. See Donald Langevoort, Theories, Assumptions and Securities Regulation: Market Efficiency Revisited, 140 U. PA. L. REV. 851, 854-55 (1992). Although the research on this issue is still highly preliminary, there is reason to suspect that investors under-react to non-salient, low-level risks. If so, we might expect that investors would be largely insensitive to the question of disclosure enforcement except, temporarily, in the aftermath of some highly salient event that calls into question the efficacy of a particular regime.

23. See, e.g., Marcel Kahan, Commentary: Some Problems with Stock Exchange-Based Securities Regulation, 83 VA. L. REV. 1509, 1517 (1997) [hereinafter Kahan, Commentary]. In advocating exchange-based regulation, Mahoney concedes this problem and suggests some need for a cooperative effort with a sovereign entity. See Mahoney, Exchange as Regulator, supra note 16, at 1498. He also suggests that the states would be appropriate enforcers. 
that comes from their status as proprietary investors and marketmakers, ${ }^{24}$ such firms also have positions of privileged access to private information through analyst contacts and the like that differ considerably from other investors. Hence, they would be uncertain champions of aggressive public disclosure obligations. And, of course, they are actively involved in the securities distribution process as underwriters. The resulting pressures on how the exchanges formulate disclosure and enforcement policy would be unpredictable and not necessarily conducive to the public good. While this problem might be minimal in an environment of intense competition for listings, the presence of such competition at the level necessary to eliminate all rent-seeking by exchange members is by no means obvious. ${ }^{25}$

As to the states or foreign countries, my concerns are different. One question is whether, absent some degree of "monopolization," individual states would have the incentives to invest in a start-up system of securities regulation and enforcement. To the extent that some administrative agency or public enforcement is desirable, perhaps on a fairly large scale, the willingness to invest taxpayer money on the bet that the state will be the "tournament" winner and be able to maintain that position over time is open to question. Beyond that, there is also an interesting question of whether the ability to regulate offerings of securities can be separated adequately from post-offering responsibilities and liabilities. $^{26}$ Integration of the 1933 and 1934 Acts is widely accepted today as both a conceptual and practical necessity. Would states then also regulate secondary trading in the issuer's stock? To do so would compound the resource pre-commitment problem noted above. Moreover, granting them the right would presumably mean that once the issuer has chosen the site of its initial public offering, it would effectively be locked into that jurisdiction unless its shareholders have consented to exit. That would be acceptable if we assume that there would be an active migration via shareholder voting to innovative jurisdictions. But I would predict a high degree of path-dependency here. The state or states that win the competition early on, for whatever reason, will have a decided advantage in their ability to expend resources, build a regulatory infrastructure, and generate a reasonable degree of confidence and stability in its system. Having taken this lead, however, the state may well begin behaving as a monopolist, threatening the benefits that would otherwise flow from true competition.

For these reasons among others, ${ }^{27} \mathrm{I}$ am not persuaded by even the theoretical arguments in favor of a move away from federal control over disclosure and

24. Their interest is a balanced one, of course. They would not want to force inefficient disclosure, or necessarily compel disclosure that would be competitively harmful to the issuer. See Edmund W. Kitch, The Theory and Practice of Securities Disclosure, 61 BROOK. L. REV. 763, 841 (1995).

25. See Kahan, Commentary, supra note 23, at 1515.

26. See, e.g., Palmiter, supra note 18 , at 105-08.

27. As an entirely separate matter, I have some doubts about the ability of states to deliver successfully on any promise to regulate and enforce efficiently. Internal political pressures (for example, government changes) constantly create situations where incumbent officials sense that they may be in a last 
enforcement in the capital-raising process. But we need not dwell too long here, for even under a decentralized system, the crucial question is one of designing the optimal liability standards.

III

\section{CONTINUOUS Disclosure LIABILITY UNDER THE 1934 ACT}

The Securities Exchange Act of 1934 is designed to promote the integrity of stock prices for publicly-traded issuers. ${ }^{28}$ If the 1934 Act succeeds in creating a healthy disclosure environment, sales of securities by issuers into a pre-existing trading market should pose minimal additional threat, and the prevailing price will be a fair one. ${ }^{29}$ On its face, at least, the 1934 Act seems well-suited to deter secondary-market price distortions.

Publicly traded issuers must file disclosure documents on a periodic basis. False statements or omissions in these documents can be sanctioned by the SEC through a variety of administrative and judicial proceedings, ${ }^{30}$ pursuant to which the Commission can seek, among other things, civil penalties and injunctive relief. In addition, and no doubt of the most substantial in terrorem concern to issuers, material falsity in such filings can trigger liability for fraud under Rule $10 \mathrm{~b}-5$, giving investors a private action for damages. Such fraud-on-the-market lawsuits are aided by judicially-created presumptions regarding reliance and causation, and can lead to massive damage exposure. ${ }^{31}$ Rule 10b-5, moreover, extends beyond required filings. Any form of issuer publicity that is reasonably calculated to affect the investing public can lead to the same combination of SEC and private liability. ${ }^{32}$

Reinforcing this threat of issuer liability are a host of "secondary" liability provisions. Lawyers and accountants, in particular, are exposed to sanction if they make misstatements directly to investors or willfully aid an issuer that misleads the investing public. ${ }^{33}$ Under some circumstances, especially for ac-

period and thus choose to act in a way that might be inconsistent with the country's reputational interest as an efficient capital-raising jurisdiction. In other words, there are agency-cost problems in the political structure. See Jonathan R. Macey \& Geoffrey P. Miller, Toward an Interest Group Theory of Corporate Law, 65 TEX. L. REV. 469, 480-81 (1987). To be sure, this problem exists at the federal level in the United States as well. But it would not necessarily be unreasonable to predict that such pressures may be less at the federal level than in the states and many foreign countries.

28. I offer this as the prevailing view. For an analysis, see Marcel Kahan, Securities Laws and the Social Cost of Inaccurate Stock Prices, 41 DUKE L.J. 977, 979 (1992). One can argue, however, that this goal is either overstated in importance, see Lynn A. Stout, The Unimportance of Being Efficient: An Economic Analysis of Stock Market Pricing and Securities Regulation, 87 MicH. L. REV. 613, 618 (1988), or historically questionable, see Paul Mahoney, Mandatory Disclosure as a Solution to Agency Problems, 62 U. CHI. L. REV. 1047, 1052 (1995).

29. That is, taking into account everything except the fact of the offering, the impact on the company's capital structure, and the intended use of the proceeds.

30. See COX ET AL., supra note 10, at 930-51.

31. See Paul Mahoney, Precaution Costs and the Law of Fraud in Impersonal Markets, 78 VA. L. REV. 623, 648-49 (1992).

32. See SEC v. Texas Gulf Sulphur Co., 401 F.2d 833, 862 (2d Cir. 1968), cert. denied, 394 U.S. 976 (1969); In re Ames Dep’t Store, 991 F.2d 953, 965 (2d Cir. 1993).

33. See COX ET AL., supra note 10, at 1009-69. 
countants, this liability is sufficiently "primary" that the actors can be liable to investors for damages under Rule 10b-5. Even when it is secondary, the Commission's authority to bring enforcement actions against aiders and abettors, and its ability to discipline professionals under Rule 102(e), ${ }^{34}$ would seem to add a significant element of deterrence for those who become intimately involved in issuer disclosure.

In addition to this legal regime are a variety of market forces that presumptively lead to high-quality issuer disclosure. One is the issuer's reputation. ${ }^{35} \mathrm{~A}$ company that misleads investors risks a lower stock price if the fraud is discovered, with a host of adverse consequences ranging from the diminished value of executive compensation packages to a higher cost of any new capital sought through the public markets. Another constraint is the intense scrutiny given to large public companies by investment analysts and the financial press. ${ }^{36}$ Such scrutiny makes fraud much more difficult to execute successfully, dampening the likelihood that it will occur in the first place.

Given all of the foregoing, it might seem difficult to imagine why large capitalization issuers would ever distort the truth and mislead investors. Yet there is a perception, particularly within the Commission, ${ }^{37}$ that compliance with 1934 Act disclosure requirements-and the truth-telling regime generally-is less than it should be, which in turn fuels the fear that primary distributions into organized secondary markets can be harmful insofar as they occur at "inaccurate" prices.

Perhaps the perception that a high degree of 1934 Act disclosure compliance is the norm is simply wrong, and regulators have seized too readily on salient but aberrant instances of misconduct. ${ }^{38}$ I am not so sure, ${ }^{39}$ however, for two reasons. First, the system of sanctions is woefully underenforced. According to conventional theory, deterrence requires an appropriate balance between the

34. Rule 102(e) gives the Commission the ability to bar professionals from practicing before it, based either on willful violations of the securities laws, willful aiding and abetting, or violations of standards of professional responsibility.

35. See Frank H. Easterbrook \& Daniel A. Fischel, Mandatory Disclosure and the Protection of Investors, 70 VA. L. REV. 669, 675 (1984).

36. See id. at 676.

37. See Aircraft Carrier, supra note 12, at 32 . It is hardly uncommon to see executives testify as to some "disinterest" in their periodic filing obligations. See, e.g., Kaufman v. Motorola Inc., [1999 Transfer Binder] Fed. Sec. L. Rep. (CCH) II 90,481 (N.D. Ill. 1999) (officers admitted that they gave "less than their full attention" to a $10-\mathrm{Q}$ filing).

38. It is hardly surprising that the Commission and its staff should have a biased view of compliance given their day-to-day focus on violations.

39. Before proceeding further, I will assume for purposes of argument that the disclosure rules themselves are well-structured. In fact, I doubt that they are-the disclosure system would benefit substantially were the Commission to expand the category of risk-related information that would have to be disclosed promptly to investors, rather than waiting for the next $10-\mathrm{K}$ or $10-\mathrm{Q}$. But this inquiry would take us too far away from the question of liability, so I will put it to the side. I do expand on this subject in Donald C. Langevoort, Toward More Effective Risk Disclosure for Technology-Enhanced Investing, 75 WASH. U. L.Q. 753, 775 (1997) (recommending that the Commission adopt affirmative disclosure requirements on a real-time basis, with appropriate privileges to conceal sensitive information). 
size of the sanction and the frequency of detection and enforcement. ${ }^{40}$ I suspect that SEC penalties are far smaller than they should be given the kinds of harm that comes from securities fraud. That is all the more true when we consider what may be the most serious flaw in the entire liability scheme: that the SEC's investigatory resources are insufficient to detect a significant portion of securities-related misconduct. ${ }^{41}$ Furthermore, those inadequate resources must be divided up in a host of areas besides seasoned issuer disclosure violations.

The SEC is forced to leave the policing of the "high end" segment of securities compliance mainly to private enforcement through class action litigation. To be sure, the activity of the plaintiff's bar is highly visible here. Moreover, it is hard to argue that the potential liability exposure for issuers in fraud-on-themarket cases is too low. It is large, probably excessively so, in light of the nature of the underlying aggregate social harm. ${ }^{42}$ Even here, however, deterrence is compromised to the extent that private securities litigation efforts detect or are perceived to detect only a fraction of meritorious cases and settle those for far less than the optimal measure of damages. While good statistics are hard to come by, I believe that (1) lawsuits are brought infrequently relative to the universe of potential disclosure violations ${ }^{43}(2)$ some significant but unknown proportion of those that are brought have little merit anyway; (3) recent legislative and judicial reforms have made meritorious cases harder to bring, ${ }^{44}$ and (4) settlements are too high in the low-merit cases and too low in the high-merit ones. ${ }^{45}$ Faced with this, issuers may perceive that the risk of detection and sanction in any given case is far less than certain, and somewhat arbitrary, insofar as even good-faith compliance can trigger litigation that has to be settled. That situation can lead to under-precaution.

While I think that there is a good bit of substance to the foregoing, it still does not sufficiently explain why issuers would take the risk of distortion or

40. See, e.g., Mitchell Polinsky \& Steven Shavell, The Optimal Use of Fines and Imprisonment, $24 \mathrm{~J}$. PUB. ECON. 89 (1984). One should take note here, however, of the finding from social psychology on criminal activity that suggests that actors are more sensitive to the probability of detection than to the size of the sanction if caught and convicted.

41. The SEC is in a difficult public posture here. Though it no doubt recognizes the need to seek more resources and indeed does so, it cannot make a public concession that it is not up to the task of regulating the markets successfully.

42. See Janet Cooper Alexander, Rethinking Damages in Securities Class Actions, 48 STAN. L. REV. 1487, 1496 (1996); Donald C. Langevoort, Capping Damages for Open-Market Securities Fraud, 38 ARIZ. L. REV. 639, 652-53 (1996) [hereinafter Langevoort, Capping Damages]; Mahoney, Exchange as Regulator, supra note 16, at 627-28.

43. This is probably a mixture of the difficulty of uncovering facts that give rise to a plausible cause of action and the economic pressures that lead to cases being brought only when there is a fairly sizable potential recovery. That latter point suggests that smaller issuers will be far less susceptible to suit, and disclosure violations that are less than dramatic will also go unremedied. On the size biases in private litigation, see James Bohn \& Stephen Choi, Fraud in the Non-Issues Market: Empirical Evidence on Securities Class Actions, 144 U. PA. L. REV. 903, 936 (1996).

44. See, e.g., Elliott I. Weiss \& Janet E. Moser, Enter Yossarian: How to Resolve the Procedural Catch-22 that the Private Securities Litigation Reform Act Creates, 76 WASH. U. L.Q. 457, 498 (1998).

45. For some statistics along these lines, see FrEDERICK DUNBAR \& VINITA JUNJEA, RECENT TRENDS II - WHAT EXPLAINS SETTLEMENTS IN SHAREHOLDER CLASS ACTIONS? (1993). 
concealment, especially when they risk incurring litigation costs and the reputational threat that join with fear of actual liability. In fact, I doubt in the abstract that issuers very often would. However, disclosure decisions are made by human beings, not companies. There is ample reason to believe that these decisions often diverge from what would be optimal in the long run from the issuer's perspective.

One well-accepted reason pertains to agency costs. Because of stock-based compensation packages, company managers may have more to gain from shortterm upward distortions in the issuer's stock price than they have to lose in the long run as an indirect result of tainting the issuer's reputation. More important, however, is the change in managerial thinking when managers sense a risk of being fired for inadequate performance. ${ }^{46}$ Then, the "long run" largely disappears from consideration, and buying time by hiding the deficiencies becomes a rational strategy. We might plausibly predict that these kinds of pressures come heavily in seasoned companies that have had sufficient levels of success to create high market expectations that, for one reason or another, become difficult to satisfy. If that company has a demanding board of directors, the threat becomes especially salient. ${ }^{47}$

This could be countered, of course, by refocusing the threat of liability on individual managers. ${ }^{48}$ On paper, managers already face serious sanctions. To the extent that they actually make misleading statements, they bear primary liability in both SEC and private lawsuits. They face the same exposure if they are deemed part of a "control group" somehow responsible for the fraud. ${ }^{49}$ The SEC has additional authority to seek penalties if their activity constitutes willful "aiding and abetting." ${ }^{50}$ Moreover, the Commission can seek a bar order against culpable executives from further serving as an officer or director of a publicly traded corporation..$^{51}$

As applied, however, these potential sanctions seem to dissolve. Private class actions often name individual defendants as a way of creating settlement pressure, but typically are settled with most of the funding, on average more than $99 \%{ }^{52}$ coming from a combination of the issuer's own treasury and its offi-

46. The classic study here is Jennifer H. Arlen \& William J. Carney, Vicarious Liability for Fraud on Securities Markets: Theory and Evidence, 1992 U. ILL. L. REV. 691. For a recent elaboration, see Mitu Gulati, When Corporate Managers Fear a Good Thing is Coming to an End: The Case of Interim Nondisclosure, 46 UCLA L. REV. 675, 693 (1999).

47. See Stephen P. Ferris et al., Monitoring By Directors with Multiple Board Appointments: Corporate Performance and the Incidence of Securities Fraud (2000) (unpublished manuscript, on file with Law \& Contemporary Problems).

48. That is the central argument in Arlen \& Carney, supra note 46, at 694.

49. According to section 20(a) of the 1934 Act, controlling persons are jointly and severally liable for securities fraud by controlled persons, unless they demonstrate that they acted in good faith and did not cause or induce the violation. See Securities and Exchange Act of 1934 § 20(a), 15 U.S.C. § 78t-1 (1994).

50 Securities Exchange Act of 1934 § 20(f), 15 U.S.C. $\$ 78 u-4$ (1994).

51. See Securities Exchange Act of 1934 § 21(d)(2), 15 U.S.C. § 78u-6 (1994).

52. See Langevoort, Capping Damages, supra note 42, at 648. 
cer and director insurance policy. And, as we have seen, these class actions are the primary enforcement mechanisms for seasoned issuer fraud.

The matter is somewhat more complicated in SEC enforcement actions. Individual sanctions are quite possible, though as we also have seen, there is a bothersome combination of sanctions that are set too low and inadequate enforcement. The bar-order process would seem to have some promise, but courts apply it with excessive reluctance. ${ }^{53}$ Moreover, executives who fear losing their jobs because of deficient performance have less to fear from being told that they also might face a bar order.

To be sure, these issues could be reformed so that there is more serious attention to individual, rather than, or at least in addition to, issuer liability. While I would support this, there are limits on what can be accomplished for two reasons. First, insurance and indemnification can take away the pain of many individual sanctions. ${ }^{54}$ Second, the rates of settlement of both SEC and private actions are high. Settlements are much easier to achieve when they do not adversely implicate the company's senior executives. Lawyers bringing private actions simply want the largest settlement they can get, and have no reason to push toward individual liability, even if it is theoretically available. SEC enforcement attorneys are under resource-driven pressures to settle as well. To gain a favorable settlement, those bringing the action may have to drop key executives entirely or limit their penalty severely.

For all these reasons, then, rational managers might take the risk of committing securities fraud. Furthermore, as I have argued elsewhere, various individual and organizational biases in risk perception can also lead to disclosure failures. $^{55}$ Distortions in information flow within an organization can lead to inadequate perception of risk at the top. Also, some kinds of risk perception may be distorted by managerial cultures of optimism and control. At the very least, I suspect that individual managers, or small groups of managers, are systematically likely to overestimate the extent to which they can successfully conceal some deficiency in their performance. ${ }^{56}$ They will engage in wishful thinking about either-or both-the likelihood that the circumstances will turn around in a more positive director or the chance that someone will come after them. Here, again, the current threat of sanctions will be inadequate.

53. See, e.g., SEC v. Patel, 61 F.3d 137 (2d Cir. 1995) (equating standard for a bar order with that for injunctive relief, therefore demanding a showing of likelihood of repetition of the misconduct).

54. On the role of insurance, see James D. Cox, Private Litigation and the Deterrence of Corporate Misconduct, 60 LAW \& CONTEMP. PROBS. 1, 21-37 (Autumn 1997). At a greater extreme, bankruptcy law can also lessen the pain of individual sanctions, which also limits the effective penalty that can be imposed.

55. See Donald C. Langevoort, Organized Illusions: A Behavioral Theory of Why Corporations Mislead Stock Market Investors (and Cause Other Social Harms), 146 U. PA. L. REV. 101, 165 (1997) [hereinafter Langevoort, Organized Illusions].

56. See id.; see also ZUR SHAPIRA, RISK TAKING: A MANAGERIAL PERSPECTIVE (1995) (emphasizing that managers often assume excessive risk because they believe they can control bad outcomes if they occur). 


\section{A. Gatekeeping Strategies}

While managers are buffered in a variety of ways from the threat of 1934 Act sanctions, there is an alternative strategy for promoting disclosure compliance: to invoke third-party enforcement, thereby adding a layer of self-policing to the system. A variety of persons associated with issuer disclosure will not necessarily share management's last period incentive to deceive or its perceptual biases. If they can be motivated to intervene to prevent or deter management fraud, the opportunity for successful deception goes down. ${ }^{57}$ There are four categories of possible intervenors to consider: executives of the issuer not directly involved in the fraud, outside directors, accountants, and lawyers.

1. Issuers and Insiders. The first two categories, other managers and directors, already have some incentive to intervene based on avoiding issuer liability and the desire to bolster the issuer's reputation. Moreover, there are existing legal provisions that can reach both when they indeed bear significant responsibility for the wrongdoing, even though they did not commit the wrong themselves. As to high-ranking executives, Section 20(a) of the 1934 Act makes controlling persons liable for a fraud in both private and public actions unless they demonstrate that they acted in good faith and did not induce the wrongdoing. Even though this provision would probably not reach someone who was simply negligent in not intervening, liability would likely follow for recklessness. ${ }^{58}$ Many courts have extended controlling person liability to the senior management team that operates the issuer on a day-to-day basis. ${ }^{59}$ SEC enforcement actions can also be effective in this setting. An executive who deliberately ignores fraudulent behavior by a colleague might be characterized as a willful aider and abettor or, even if simply negligent, as a substantial cause of the violation in a cease-and-desist proceeding. ${ }^{60}$ Outside directors may be harder to reach under these theories ${ }^{61}$ but that is probably appropriate given the limited involvement such directors usually have. When directors are in some sense culpable participants, they too can fit into the existing set of prohibitions and sanctions. ${ }^{62}$

57. This is the fairly familiar "gatekeeper" strategy of regulation. See Reinier Kraakman, Corporate Liability Strategies and the Costs of Legal Controls, 93 YALE L.J. 857, 867 (1984).

58. See Donohoe v. Consolidated Operating \& Prod. Corp., 30 F.3d 907, 911 (7th Cir. 1994); Cox ET AL., supra note 10, at 1027-32.

59. See Wool v. Tandem Computers Inc., 818 F.2d 1433, 1440-41 (9th Cir. 1987).

60. See Bruce Hiler \& Neil Gilman, The SEC's Use of its Cease-and-Desist Authority: A Survey, 23 SEC. REG. L.J. 235, 250-52 (1995).

61. It is a fact question as to whether an outside director has the kind of involvement that rises to the level of control, and given the more limited involvement generally, it is probably easier for them to show good faith. For an illustration, see Jacobs v. Coopers \& Lybrand LLP, [1999 Transfer Binder] Fed. Sec. L. Rep. (CCH) II 90, 443 (Feb. 26, 1999).

62. For a controversial proceeding charging two directors with complicity in the filing of a false report where they knew the underlying facts but apparently were advised by counsel that disclosure was adequate, see In re W.R. Grace \& Co., [1998 Transfer Binder] Fed. Sec. L. Rep. (CCH) II 85, 963 (Sept. 30, 1997). 
What is missing here, at least from the legal standpoint, is a stronger incentive for the issuer's officers and directors to implement procedures designed to prevent 1934 Act violations. Arguably, the existing threat of issuer liability, not to mention reputational incentives, should be sufficient to cause this to happen. However, I am skeptical. It assumes much in the way of existing officer/director incentives to monitor proactively given the demands on their time and attention. ${ }^{63}$ For this reason, there is some justification for imposing an affirmative statutory requirement of an adequate internal controls system for disclosure accuracy. Such a requirement already exists with respect to internal accounting controls under Section 13(b)(2)(B) of the 1934 Act; this would simply be an extension to the full range of periodic disclosure compliance. Programs such as these already exist in many companies, both with respect to filings and continuous disclosure matters. ${ }^{64}$ The hard question, of course, has to do with the liability consequences: Should directors be personally liable if they fail to put an appropriate control system in place $?^{65}$ Questions of defining the appropriate level of care within a particular company and establishing causation between the system failure and the wrongdoing are highly indeterminate. As a result, any effort to tie negligent supervisory breakdowns to officer-director fraud-on-themarket liability could result in excessive liability, excessive precaution, and a higher level of speculative litigation. If so, we might want to limit enforcement to SEC actions, for example, cease-and-desist proceedings. On the other hand, we should recognize once again the Commission's limited investigatory resources; sanctions must be larger than those currently in the Commission's arsenal if they are to have a useful deterrent effect. It might also be true that the system of proportional liability that Congress introduced in 1995 could assure that class action damages are fairly limited in "failure to prevent" settings, in which case excessive precaution concerns would be diminished. ${ }^{66}$

In the face of this ambiguity, I would offer a simpler, "carrot-like" solution. I have suggested elsewhere and still believe that generally, open-market securi-

63. See Arlen \& Carney, supra note 46. In addition, I suspect that board insistence on preventive steps before any wrongdoing occurs sends an awkward signal of distrust within many corporate cultures. See Donald C. Langevoort, The Epistemology of Corporate-Securities Lawyering: Beliefs, Biases and Organizational Behavior, 63 BROOK. L. REV. 629, 667-72 (1997) [hereinafter, Langevoort, Epistemology of Corporate-Securities Lawyering]. As organized compliance programs become more the norm, this concern diminishes considerably. Nonetheless, there is a difference between the typical compliance program — which is company-wide — and one dealing with disclosure compliance, which by and large targets upper management.

64. See, e.g., RePORT OF THE NAT'L ASS'N OF CORPORATE Directors Best Practices COUNCIL, COPING WITH FRAUd AND OTHER ILLEGAL ACTIVITY (1998).

65. This parallels an issue under state corporation law. See In re Caremark Int'l Inc. Derivative, 698 A.2d 959 (Del. Ch. 1996).

66. Section $21 \mathrm{D}(\mathrm{g})$ requires an allocation of proportionate fault to those persons found liable for a securities law violation so long as they did not act with "actual knowledge" of the violation. See Securities Exchange Act of 1934, 15 U.S.C. $§ 21(\mathrm{~d})(\mathrm{g})$ (1994). See Donald C. Langevoort, The Reform of Joint and Several Liability Under the Private Securities Litigation Reform Act of 1995: Proportionate Liability, Contribution Rights and Settlement Effects, 51 BUS. LAW. 1157, 1162-68 (1996) [hereinafter Langevoort, Proportionate Liability]. 
ties fraud damages should be capped. ${ }^{67}$ An alternative strategy, however-borrowing from the Organizational Sentencing Guidelines ("OSG") in criminal law-is to limit issuer damages in fraud-on-the-market cases if the issuer demonstrates that it had a reasonable system of internal disclosure procedures in place. Here, the question would not be one of causation, and the inquiry would simply go to the amount of liability. ${ }^{68}$ By most accounts, directors have become much more willing to invest in compliance efforts generally in response to the OSG. ${ }^{69}$

This approach is superior to a related alternative creating a negligencebased system of liability for issuers, and perhaps senior executives, if their periodic disclosures contain false statements or actionable omissions. The American Law Institute's Federal Securities Code, as initially drafted, contained a due diligence requirement for false $10-\mathrm{Ks}$, but this proposal received substantial opposition even though the measure of damages resulting from a violation would have been capped. ${ }^{70}$ Allowing a class action to go forward without evidence of scienter on the part of any of the issuer's managers responsible for the disclosure invites a great deal of speculative or extortionate litigation. ${ }^{71}$

2. Outsider Liability. The suspicion that insiders have incentives or biases to mislead, and that outside directors may not be well motivated or positioned to counter them, has long led to the use of a variety of alternative "gatekeeper" strategies under the securities laws. These are strategies that enlist certain outsiders with a strong reputational stake to certify or "bond" the accuracy of an issuer's disclosures. Under the 1933 Act, underwriters and accountants are forced to play this role, facing Section 11 liability if they fail to exercise due diligence or ignore red flags suggesting false or misleading issuer disclosure. Consistent with the spirit of gatekeeper liability, courts have construed the due diligence standard to require these outsiders to play the role of "skeptic" refusing to take management's representations about the true state of affairs on face value. ${ }^{72}$

The use of gatekeeper strategies is more subtle under the 1934 Act, where accountants and lawyers are the major candidates for the assigned role. Private

67. See Langevoort, Capping Damages, supra note 42, at 657-62.

68. To the extent that the purpose of the full measure of damages was truly compensatory rather than deterrent, there would be reason for concern. See, e.g., COX ET AL., supra note 10. However, for reasons I have stated elsewhere, I believe that the measure of fraud on the market damages is supra-compensatory.

69. Caremark has also been a motivator, see 698 A.2d at 959 (suggesting that personal liability concerns are not entirely irrelevant); see also PRACTICING LAW InST., CORPORATE COMPLIANCE AFTER CAREMARK, (No. B-995) (1997). On the design of such systems today, see Linda Trevino et al., Managing Ethics and Legal Compliance: What Works and What Hurts, 41 CAL. MGMT. REV. 131 (1999).

70. See Federal SEC. CODE $\$ \$ 705-06$ (1981).

71. Scienter-based pleading requirements are seen as a crucial means of limiting speculative fraudon-the-market litigation. See Weiss \& Moser, supra note 44. On the other hand, such an approach might be a useful approach to countering managerial biases. See Langevoort, Organized Illusions, supra note 55, at 126-29.

72. See Escott v. Barchris Const. Co., 283 F. Supp. 643 (S.D.N.Y. 1968). 
liability arises for all practical purposes only upon a showing that a party was sufficiently involved in the issuer's disclosure to make it "primarily" liable, and then only if that party acted with scienter. Many courts have adopted narrow readings of what constitutes primary liability - excessively so, in my view ${ }^{73}$ - and at least a few have taken aim at scienter by questioning whether conventional recklessness suffices. ${ }^{74}$ With respect to SEC enforcement, the ability to charge secondary participants as aiders and abettors broadens the scope of liability, but this is tied to willful misconduct. One has to go to the administrative proceedings level to find sources to go after secondary participants who act negligently. This can be done in cease-and-desist proceedings, ${ }^{75}$ and as against accountants, at least in disciplinary actions under Rule $102(\mathrm{e}) .^{76}$

All this can hardly be called an aggressive legal regime. The natural question, then, becomes whether securities regulation should try to use the threat of liability to force more extensive external certification efforts with respect to secondary marketplace disclosure. The purpose behind such a thought is twofold. First, it recognizes the importance of disclosure for the benefit of the secondary marketplace even if the issuer is not at the time selling any securities. Second, it reflects the increasing recognition-to be explored in more detail infra-that external due diligence associated with public offerings by large issuers is impractical, and so operates as a periodic substitute for underwriter due diligence. Merritt Fox, for instance, has suggested an external certification on an annual basis, with sizable due diligence-based liability exposure. ${ }^{77}$ James Cox $^{-}$ has recommended a triennial certification. ${ }^{78}$

I find these proposals attractive in the abstract: External certification on a periodic basis does impose a discipline and a deterrence to the kind of "lastperiod" managerial misbehavior noted earlier, and offers a helpful antidote to internal biases in managerial risk perception. ${ }^{79}$ I am inclined toward more frequent review $^{80}$ on the ground that last-period problems are likely to arise within

73. The courts differ substantially on what is required for "primary" liability. Some give it a fairly broad reading, imposing liability essentially on those who can be called "co-authors" of the misleading disclosure, even if they worked behind the scenes. See, e.g., In re Software Toolworks, 50 F.3d 615 (9th Cir. 1994). I find this line of cases appealing. See Donald C. Langevoort, Words from on High About Rule 10b-5: Chiarella's History, Central Bank's Future, 20 DEL. J. CORP. L. 865, 888-93 (1995). However, other courts have been much more restrictive, insisting on some degree of visibility as an author before the participant can be charged with liability. See, e.g., Wright v. Ernst \& Young LLP, 152 F.3d 169, 175 (2d Cir. 1998); Anixter v. Home-Stake Prod. Co., 77 F.3d 1215, 1226-27 (10th Cir. 1996).

74. See In re Silicon Graphics Sec. Inc., 183 F.3d 970, 979 (9th Cir. 1999).

75. See Hiler \& Gilman, supra note 60, at 255-58.

76. See Amendments to Rule 102(e) of The Commisions Rules of Practice, Securities Act Release No. 7,593 [1998 Transfer Binder] Fed. Sec. L. Rep. (CCH) II 86,052, at 80,843 (Oct. 19, 1998), responding to Checkosky v. SEC, 139 F.3d 221 (D.C. Cir. 1998).

77. See Fox, supra note 11, at 913-17.

78. See James D. Cox, The Fundamentals of an Electronic-Based Federal Securities Act, 75 WASH. U. L.Q. 857, 883-86 (1997).

79. See Langevoort, Epistemology of Corporate Securities Lawyering, supra note 63, at 663-64; Langevoort, Organized Illusions, supra note 55, at 158-60.

80. Former SEC Commissioner Steven Wallman, for instance, has suggested that the audit function gradually will move toward "continuous" certification of the process by which disclosure and financial 
short timeframes that can easily fall between scheduled investigations. ${ }^{81}$ The questions are who should do the investigation, what their charge should be, and what the liability consequences should be when there is a failure. Lurking beneath all this and highly dependent on the answers to the foregoing questions is the practical issue of whether qualified certifying institutions will be available to do this kind of work.

If we move toward a model of annual certification of disclosure accuracy, the initial question is whether this should be a wholly new system of certification, as both Fox and Cox recommend, or simply an expansion of the current annual certification required under the 1934 Act that is provided by the independent audit. What institution is most likely to perform well? Due diligence in the public offering setting is largely done by lawyers for the issuer and the underwriters, to which is added the accountants' expertised work. One could envision a similar structure under the 1934 Act. Very little about such investigation, however, requires legal, much less investment banking, knowledge. Rather, what is required is a detailed, often industry-specific, knowledge of business practices and likely hidden problems. On balance, I would predict that accountants have a sizable informational and expertise advantage in this area. ${ }^{82}$ Indeed, the auditing function has grown to encompass more fraud detection and internal controls in recent years. ${ }^{83}$ It is not difficult to imagine that the SEC and the accounting profession could negotiate an even more refined understanding of the audit function that would capture much of what public-offering due diligence would be if applied to the 10-K. No doubt the accountants would want to utilize lawyers and other professionals in this process, but they would remain in control.

Suppose that such a disclosure audit requirement is articulated, and the auditors failed to do an appropriate job. What should their liability be? Without any statutory change, the answer was described earlier: They would be liable under Rule 10b-5, but only to the extent that they knew or recklessly disregarded the management fraud. If their culpability were based simply on recklessness, they would take advantage of proportionate liability in a private

reporting is created, matching with a move toward more continuous electronic disclosure by issuers. See SEC's Wallman Describes View of Technology's Impact on Accounting, 28 Sec. Reg. \& L. Rep. (BNA) 1531 (Dec. 13, 1996). While this substantive change is beyond the scope of this paper, it is consistent with what I would propose in terms of the nature of the disclosure obligation. See supra text accompanying notes 8-12.

81. This point is emphasized in Gulati, supra note 46, at 713-16. Even with annual certifications, there is time for such pressures to build and distort disclosure.

82. In an IPO, due diligence has a broader purpose assuring that the nature of the issuer's business and its attendant risks are effectively communicated to investors. Given that issuer's management has little experience in disclosure, outside certification plays an important role even if we assume that the managers are honest. In the continuous disclosure environment, however, this role is far less important-especially for larger issuers. In such a setting, management fraud defined to include a broad array of managers within an organization is the only real justification for external certification.

83. See Codification of Accounting Standards and Procedures, Statements on Auditing Standards No 82, § 316 (American Inst. of Certified Pub. Accountants 1997). The report of the "Treadway Commission" on financial fraud reporting was an important step in this evolution. 
action for damages. SEC sanctions might be available for lesser forms of misconduct.

An intriguing alternative, suggested by Fox, is negligence-based liability to private investors. $^{84}$ In an ideal world in which only justifiable lawsuits were brought and courts resolved legal and factual disputes accurately, this alternative would be attractive. Problems of extortionate litigation, hindsight bias, and legal indeterminacy, however, suggest that auditors would reasonably demand a sizable risk premium for engaging in this service, and might, once engaged, be overly cautious, layering unnecessary cost on the audit function. Of course, proportionate liability would limit liability exposure in many cases, but the comfort it would offer ex ante is hard to estimate. My preference would be to bifurcate liability: Private actions could go forward, as today, only upon a showing of scienter. Liability for audit failures short of knowing or reckless misconduct would occur via public enforcement. To the extent that concerns about the shortage of SEC resources lead one to conclude that this does not provide sufficient deterrence, a second-best solution might be a negligence-based regime with an explicit cap on damages (for example, at some multiple of the audit fees). ${ }^{85}$

There is a risk that existing audit firms would refuse to provide the expanded level of service, especially if liability exposure were relatively broad. ${ }^{86}$ There are fears that large multi-service accounting firms already find the audit function less profitable than other lines of business, and would hesitate to cooperate in any expansion. That concern is strange given that it is implicitly premised on a high level of oligopoly behavior within the accounting profession. Normally, prices would simply rise or new entrants would emerge to provide the appropriate level of supply. ${ }^{87}$ Were the oligopoly problem to be intractable, the second-best move would be toward non-accountant certification, which no doubt could appropriate a segment of the industry's expertise in detecting management fraud. ${ }^{88}$

84. This was also the original proposal in the ALI's Federal Securities Code. See FEDERAL SEC. CODE $\S \S 705-06$ (1981).

85. In all these settings, there is the separate question of compensation for victims of financial fraud. My sense, however, is that in "fraud on the market" cases, at least, questions of compensation are very much secondary to deterrence. See Langevoort, Capping Damages, supra note 42, at 651-62.

86. An excellent survey of the accounting profession's concern with liability is Richard Miller \& Michael Young, Financial Reporting and Risk Management in the 21st Century, 65 FORDHAM L. REV. 1987 (1997).

87. The recent "Elliott Committee" of the AICPA is actually optimistic that the accounting profession would want to expand the assurance services it offers to include certification beyond standard disclosure, though it does note concerns about liability as a potential barrier. This report is available on the AICPA web site (visited Sept. 27, 2000) <http://www.aicpa.org/assurance/scas/index/htm >. See also Robert Mednick, Reinventing the Audit, 172 J. ACCT. 71, 74-75, 78 (1991).

88. In the Aircraft Carrier, the Commission sought comment on whether underwriter due diligence in connection with an offering should be relaxed to the extent that an "independent qualified professional" did a year-end disclosure review and investigation. Conceding that such a practice is not currently common, the Commission no doubt was seeking to encourage it. The Commission was careful to avoid choosing a particular kind of professional to do this job, and explicitly asked for comment about 


\section{B. Summary}

The existing 1934 Act structure would be perfectly acceptable were it to be enforced at an optimal level. Short of this, there is a virtue to enlisting boards of directors to play a greater role in disclosure compliance. Rather than insisting on largely symbolic signature requirements, however, a more helpful step would be a requirement that boards take reasonable systematic steps to assure compliance with periodic disclosure obligations. The best way to encourage directors to take this seriously, but not to act overcautiously, would be to limit issuer damages in fraud-on-the-market cases upon a showing that reasonable disclosure compliance procedures were in place even though they failed to prevent the fraud.

Second, there is a virtue to annual investigation by an external "certifier" with respect to the accuracy of the issuer's 10-K. On balance, I think that an expanded conception of the audit function most efficiently satisfies this need and would thus work effectively to merge the notions of due diligence and audit. As to liability, I would prefer a Rule 10b-5-based system, with a more serious agency commitment to cease-and-desist and Rule 102(e) enforcement in cases of negligence.

IV

\section{REVISING SECTION 11: LIABILITY UNDER THE SECURITIES ACT OF 1933}

The current integrated disclosure structure for 1933 Act compliance by large issuers rests on the concept of incorporation by reference. The company's periodic disclosure filings, for example, 10-Ks, 10-Qs and 8-Ks, are deemed part of the registration statement, although they must be updated to reflect new information not previously reported. Thus, the issuer bears strict liability if any of this incorporated disclosure information is false or misleading at the time of effectiveness, and all the other Section 11 defendants, including the underwriters, have due diligence responsibilities with respect to it. The recent SEC proposals would continue this approach of broad in terrorem liability. ${ }^{89}$

There are two reasons to reconsider this policy. First, is this system fair in an environment that encourages issuers to act quickly in seizing windows of marketplace opportunity to sell shares? $?^{90}$ This concern has existed ever since the integrated disclosure and shelf registration rules were established in the early 1980s. There may be no time for serious due diligence between the decision to proceed, at which point the underwriters are selected and notified, and the sales. That puts everyone, but especially the underwriters, in an uncomfort-

whether a market for such services would develop, especially in the face of liability threats. See Wallman Commission Report, supra note 12, at 158-59.

89. Aircraft Carrier, supra note 12, at 160 (choosing not to deregulate with respect to underwriter liability exposure).

90. This concern is well articulated in the article by the American Bar Ass'n Comm. on the Federal Reg. of Securities, Report of the Task Force on Seller's Due Diligence and Similar Defenses Under the Federal Securities Laws, 48 BUS. LAw. 1185 (1993). 
able position given the size of the liability exposure. Rule 176 attempts to provide some comfort by suggesting that there can be some relaxation in diligence under the circumstances, but delivers little assurance because it fails to create a determinate safe harbor. The effect of the discomfort is some combination of finger-crossing during a public offering and pressure to structure capital-raising deals in the form of Rule 144A offerings, private placements, and offshore offerings in ways that avoid Section 11 exposure. These pressures no doubt would become even more problematic as technology expands the capital-raising options available to large companies, giving them options well beyond the conventional underwritten distribution. ${ }^{91}$

The other reason to consider reform, articulated by Michael Dooley, ${ }^{92}$ and more recently by Stephen Choi, ${ }^{93}$ is the suspicion that strict Section 11 liability may not be cost justified, at least as applied to large capitalization issuers. Such issuers, they argue, have substantial reputational incentives to be candid in their capital raising, and to select underwriters with an even greater reputational stake in candor. As noted earlier, the presence of widespread analyst and press scrutiny of such issuers makes fraud that much more difficult. None of this implies that fraud will not occur on occasion, simply that it is less likely to be successful in this context. As such, the economic benefit from expensive, ritualistic due diligence is reduced. Under these circumstances, it is not surprising that issuers migrate toward the various, but otherwise suboptimal, alternatives to public offerings, because Section 11 does not offer reasonable value to investors.

\section{A. Issuers and Insiders}

For reasons that were discussed earlier relating to the last period problem, I am not convinced that reputational concerns are likely to be a sufficient check on issuer overreaching in a public offering. Indeed, as Mitu Gulati has argued, ${ }^{94}$ it is precisely the seasoned issuer whose management will be most sorely tempted to engage in a public offering at an inflated price as a strategy to hold onto their jobs and perhaps turn the company around. Even if the company is not in distress, there might be a temptation to inflate the company's prospects to the extent that high-level insiders are using registration as an occasion to sell a sizable portion of their own shares.

91. Though internet-based offerings currently exist only in small numbers and only for relatively small issuers, there is ample reason to believe that it is the larger issuer-with an established reputation among investors - that can best take advantage of direct offerings to investors.

92. See Dooley, supra note 5, at 801 .

93. See Stephen Choi, Company Registration: Toward a Status Based Antifraud Regime, 64 U. CHI. L. REV. 567, 567-78 (1997) [hereinafter Choi, Company Registration].

94. See Gulati, supra note 46, at 696-709.

95. Rationally, this temptation should be limited to the extent that the selling shareholders will be retaining many of their shares. I suspect, however, that as for many human beings, the temptation to do what it takes to get money "now" can overwhelm longer-term incentives. 
That suggests the need to retain some system of issuer liability under Section 11-with a strong emphasis on insider responsibility. It would not necessarily justify the prevailing system of strict liability for the issuer and due diligence liability for signatory officers and the company's inside directors. After all, actual fraud is remediable under Rule $10 \mathrm{~b}-5 .^{96}$ Moreover, at least to the extent that we already have a workable disclosure system under the 1934 Act, with appropriate liability and enforcement, we already have deterrence targeting the company's periodic disclosure that, in turn, becomes the heart of disclosure on Form S-3 and would do so as well under the Aircraft Carrier's proposed Form B.

Nonetheless, an internal due diligence requirement for insiders makes a great deal of sense to me. It is, of course, possible to have pervasive frauds involving most or all of the company's top managers in seasoned companies, but that is rare. Engineering a fraud that involves a large number of people is difficult and dangerous. In many fraud cases, only a segment of senior management will be aware of the deception. ${ }^{97}$ Sometimes, lower-level managers are involved. As a matter of law, it is possible that the knowledge of any company agent or employee will be attributed to the company. However, this is not entirely clear from a doctrinal standpoint, ${ }^{98}$ and could arguably be subject to an exception if the employees hiding the truth are engaging in corrupt or self-serving behavior.

A due diligence obligation makes especially good sense as applied to noninvolved senior executives. They are in the best position to assess credibility and test the company's weak points, and absent something like Section 11, have no obvious legal obligation to make inquiries. ${ }^{99}$ There probably is also some social deterrence to a regime wherein if one manager hides the truth, she exposes her peers to liability. Furthermore, this kind of liability regime tells those in control of the timing of the offering to forego a sale when they sense that key information is in flux or there are red flags about the company's situation.

For all these reasons, I would maintain the current liability regime as applied to insiders of the issuer. ${ }^{100}$ The remaining question, then, is whether strict liability is justified for issuers, or whether the issuer should be relieved from Section 11 liability if it can show that it implemented and applied appropriate procedures to discover the truth and failed notwithstanding all reasonable effort. To me, the question is a close one, and is tightly connected to the general problem of vicarious liability. On balance, I am persuaded that the issuer should be liable, without regard to the actual and often hard to evaluate quality

96. The remedy is perhaps suboptimal in terms of the incidence of enforcement. See supra text accompanying note 31 .

97. For a study of recent financial frauds, showing that the CEO engineers a large portion of them, see Mark Beasley et al., Fraudulent Financial Reporting: 1987-1997 - An Analysis of U.S. Public Companies (visited Aug. 24, 2000) <http://www.aicpa.org/news/p032699b.htm>.

98. See Langevoort, Organized Illusions, supra note 55, at 126-29.

99. Socially, they are under a great deal of pressure to "look the other way."

100. It is an interesting question as to whether this should really be "due diligence" (that is, an affirmative investigatory obligation) or simply a negligence-based regime (that is, a duty not to ignore red flags). With respect to senior managers, I doubt that the difference is all that great. 
of its monitoring, if the deception was the fault of someone in the organization, and hence could have been prevented or detected. ${ }^{101}$

\section{B. Outside Directors}

Outside directors currently have due diligence responsibilities, but they are the explicit beneficiaries of statutory reform in 1995 that eliminated joint and several Section 11 liability in favor of proportionate liability, so long as they did not actually know of the fraud. ${ }^{102}$ Although there are no decided cases on the issue and may never be, given the dearth of Section 11 trials, one would expect that few judges or juries would assign much of the liability load to non-complicit outside directors.

In this light, should they have any liability exposure at all, absent knowledge of the fraud or perhaps reckless disregard? My sense is that little justification exists for doing so. The strong system of issuer liability provides a large incentive in and of itself to be careful in assuring that appropriate detection and reporting systems are in place as a preventative measure. Under these circumstances, the main impact of individual director due diligence liability may be simply to increase the pressures for settlement of weak cases. I would, however, retain outside director liability directly under Section 11 when scienter can be established, given open questions regarding who is primarily liable for fraud under Rule $10 \mathrm{~b}-5 .^{103}$

\section{Underwriters}

Most commentators agree that an underwriter who knows or recklessly disregards a material misstatement or omission in a registration statement or incorporated disclosures should be liable under Section $11 .^{104}$ The more heavily contested question is whether to continue to insist on due diligence liability in short form registrations under circumstances where there is little practical opportunity for a de novo investigation. The SEC's response, initially via Rule 176 and now with proposed amendments, is "yes but." Underwriter liability is maintained, but the definition of what constitutes due diligence is modified in certain kinds of transactions to "take account of" the collapsed timing attendant to short-form offerings. ${ }^{105}$ No court has ever been called upon to interpret Rule 176 , and so it is difficult to know what level of comfort it creates. The Commis-

101. Here, we must acknowledge that Section 11 plays a compensatory as well as deterrence role. Under tort law generally, agency law doctrine tends to impose strict liability on a company for frauds committed in the company's name. See In re Atlantic Fin. Mgmt. Corp., 784 F.2d 29, 31-32 (1st Cir. 1986). On the general role of vicarious liability, see COX ET AL., supra note 10, at 1023-32.

102. See Langevoort, Proportionate Liability, supra note 66, at 1164.

103. That is to say, I would use a Rule 10b-5 standard for liability, but expand it so that outside directors would be liable if they were aware of the fraud but failed to act. Such inaction would not meet the test for "primary liability" as currently understood. See supra text accompanying note 73.

104. But see Stephen Choi, Market Lessons for Gatekeepers, 92 Nw. U. L. REV. 916, 962 (1998) [hereinafter Choi, Market Lessons].

105. See Aircraft Carrier, supra note 12 at 152-60. 
sion, at least, believes that the current situation is satisfactory, and that meaningful, if truncated, due diligence does occur in short-form offerings. Hence, the proposed revisions to the Rule simply expand on the kinds of steps the Commission deems appropriate under these circumstances.

There are three stronger alternatives to consider. One is to turn an amended Rule 176 into a true safe harbor, providing immunity to underwriters who follow its guidelines. The problem with this approach is that the standards themselves are somewhat ambiguous and open-ended, providing no obvious roadmap to safety. To be more determinate, they must provide protection upon a showing that the underwriter made a good-faith effort to follow the guidance. While this is possible, it leaves open the question of whether the underwriter due diligence liability is then so diluted that it adds little to the cause of investor protection. The second option is to eliminate the due diligence responsibility but retain a negligence standard for liability, making clear that the underwriter's duty is simply to respond to visible warning signs. The final possibility is jettisoning underwriter liability completely, absent a showing of scienter.

The key to resolving this issue is determining, from a policy standpoint, what kind of underwriter intervention we want prior to a short-form offering. Based on the SEC proposals and common sense, there is good reason to expect an underwriter to carefully review prior filings that would be incorporated by reference and to meet with executives of the issuer to ask questions and to examine any further filings that would be made to update existing disclosure. No doubt, a part of this anticipated discussion would be to review the issuer's internal control and disclosure procedures. Underwriters will also likely draw on the knowledge of investment analysts, who presumably have a fairly detailed knowledge of the issuer and its competitive environment.

This is quite different from due diligence as conventionally understood, which involves a form of devil's advocacy. This requires a second look at primary source material-for example, the re-examination of key contracts to assure that managers are telling the truth. ${ }^{106}$ That is the kind of diligence that is impracticable in short-form offerings. ${ }^{107}$ We could achieve this stepped-down level of diligence through the establishment of a safe harbor that specifies that a review of filings and questioning of management in light of information otherwise available to the issuer satisfies the investigation portion of the due diligence defense in Section 11(b). However, I suspect that we would end up at exactly the same place if we replaced the due diligence standard with one based on negligence. It is hard to imagine that underwriters would not reach that minimal level of inquiry anyway. They have the brokers' "shingle theory" obli-

106. See Escott v. Barchris Const. Co., 283 F. Supp. 643, 682-83 (S.D.N.Y. 1968).

107. That is, between the time of the decision to sell and the actual sales. One could say that underwriters must, constructively at least, do some sort of anticipatory due diligence. I would suggest that this is a role better assigned to accountants with respect to the potential for management fraud. See supra text accompanying note 71 . 
gation to worry about, which requires some inquiry into securities being recommended, ${ }^{108}$ as well as the fear that no inquiry at all would constitute reckless disregard under Rule 10b-5. An SEC enforcement action under Section 17(a), which has a negligence standard built into it ${ }^{109}$ is also possible. Even aside from any legal incentives, underwriters' concern about reputation demands some degree of care before associating with a distribution. As to the kind of information that can be obtained from analysts, that information is presumably already incorporated into the price of the stock for widely-followed companies.

Conceptually, I might favor one or the other of the foregoing approaches. Yet, there is a strong practical case to be made for absolving underwriters of all inquiry obligations short of recklessness. Given the reputational stakes, a substantial review is likely to occur anyway, and it is questionable whether the threat of negligence-based legal liability is really needed to get underwriters to avoid involvement in an offering when they spot danger signs. The downside of a negligence standard is its indeterminacy, especially as applied in hindsight. I suspect that some risk premium will attach to underwritten offerings simply to reflect the incidence of low-merit lawsuits that are brought in the hopes of judge or jury error, or just for the settlement value. Whatever the merits of securities litigation reform procedures generally, they do help weed out weak scienterbased cases. No such procedure is as readily available for negligence cases, given the difficulties attendant to assessing reasonableness. ${ }^{110}$ In light of the low level of added value from underwriter involvement in short-form disclosures in any event, there is a legitimate question about whether this cost is justifiable. If not, it distorts capital raising choices.

The other reason for removing non-scienter liability from underwriters has to do with technological evolution: It is quite probable that reputable issuers will find means for distributing their securities in a public offering in a way that does not employ the conventional underwriter at all. Yet, some assistance in the distribution may be needed (for example, through the use of internet marketing), and the definition of underwriter is broad enough to cover these activities. As underwriter involvement diminishes in significance relative to the deal as a whole, it becomes that much more problematic to apply a negligence-based standard in the first place. Indeed, the threat of negligence liability could frustrate the development of otherwise useful, but less than full-service, capitalraising mechanisms for large capitalization issuers. ${ }^{111}$

None of this, of course, precludes a voluntary assumption of a greater investigatory or certification obligation by an underwriter or other intermediary. A company that believes that investors would be more receptive to an offering if a

108. See Roberta Karmel, Is the Shingle Theory Dead?, 52 WASH. \& LEE L. REV. 1271, 1276 (1995).

109. See Aaron v. SEC, 446 U.S. 680, 684-85 (1979).

110. On the use of pleading restrictions in Section 11 cases, see Hillary Sale, Heightened Pleading and Discovery Stays: An Analysis of the Effect of PSLRA's Internal Information Standard on 1933 and 1934 Act Claims, 76 WASH. U. L.Q. 537, 590-93 (1998).

111. See Donald Langevoort, Information Technology and the Structure of Securities Regulation, 98 HARV. L. REV. 747, 776-78 (1985). 
full due diligence investigation had been made, should be free to have the intermediary state the level of investigation undertaken and report its findings. To the extent that there was a deliberate or reckless failure to do the job as described, fraud liability under Rule $10 \mathrm{~b}-5$ would attach. However, mere negligence in carrying out that task would not trigger liability. ${ }^{112}$

\section{Extending the Reforms: Smaller Companies and Exempt Offerings}

1. IPOs and Non-World Class Issuers. If there is a good case for revising Section 11, should it extend to settings other than public offerings by large capitalization issuers? We can begin with an initial public offering ("IPO"), a distribution by an issuer that creates public company status. There is an apparent reputational incentive to be truthful in such offerings, in that the relatively youthful issuer probably intends to tap the capital marketplace numerous times in the future. ${ }^{113}$ This aside, however, the other justifications for deregulation do not appear. ${ }^{114}$ Companies on the verge of attaining public status are typically not widely followed by analysts, and, because there is no preexisting public market, there is no market-price check on the pricing of the distribution. The underwriters for IPOs tend on average to be less prestigious, though, again, they may be interested in building their reputation-and hence quite diligent. ${ }^{115}$ Management may be less well-organized, and hence have less than desired awareness of the company's resources and competitive situation. Often, founding shareholders are selling out a considerable portion of the holdings, creating a modified last-period incentive toward overly optimistic disclosure. For all these reasons, strong external certification seems warranted.

The question becomes more difficult when we move to seasoned public companies that do not meet the size standard to justify short-form registration generally. Because the size test is a proxy for how widely followed the company is, and hence how efficient its market is, we are considering here companies that are traded in markets where we have less confidence that there is an external pricing check on managerial overreaching. This category is quite diffuse, including some companies that are ascending toward large-cap status, as well as those who have never achieved much success, or whose prospects are falling, but have nonetheless avoided extinction. Others are stable firms in smaller or more specialized product markets.

Without delving deeply into the appropriate standards for long versus shortform disclosure, my sense is that the liability structure should be tied to the regulatory judgment about how necessary special disclosure is for investor pro-

112. Stephen Choi suggests a regime that would allow underwriters to choose a liability level-presumably under a system wherein the issuer compensates it for bearing a higher level of legal risk in order to achieve a greater level of credibility. See Choi, Market Lessons, supra note 104, at 951-57.

113. See Gulati, supra note 46, at 692-99.

114. See Choi, Company Registration, supra note 93; but see Palmiter, supra note 18.

115. See Carter \& Manaster, Initial Public Offerings and Underwriter Reputations, 45 J. FIN. 1045 (1990). 
tection. Arguably, though no comparable judgment is found in current law, short-form registration might be made available for equity offerings that are in an amount less than some percentage of the current market value of the firm's existing equity securities. These limited public offerings are less likely to tempt management to cheat.

2. Exempt Offerings. Until the Supreme Court's decision in Gustafson v. Alloyd Corp. ${ }^{116}$ most courts and commentators believed that under Section 12(a)(2) of the 1933 Act, issuers and persons who solicit investors on behalf of issuers were liable for misstatements or omissions, even when the offering was exempt from registration. Because Section 12(a)(2) uses a negligence standard, this was thought to impose some sort of due diligence obligations on private offerings, though it was unclear precisely how much diligence was due. ${ }^{117}$ In Gustafson, however, the Court employed an unusual, and for the most part roundly criticized, ${ }^{118}$ method of statutory construction to conclude that the scope of that section is limited to false or misleading statements in public offering materials.

Because we are rethinking the liability structure of the 1933 Act as a conceptual matter, we need not worry about the Court's interpretive methodology. What about the desirability of the result? To be sure, the issue of whether a negligence standard should apply in private offerings may be a federalism question. ${ }^{119}$ Most states would apply the tort of negligent misrepresentation to these kinds of sales, and the small nature of the offering typically would make state courts a suitable forum for resolving these disputes. That is beside the point conceptually. Moreover, there are certain kinds of exempt offerings that occur on a fairly widespread, multi-state basis, such as offerings of limited partnership interests during the $1980 \mathrm{~s},{ }^{120}$ where there would be a virtue to federal court resolution of the claims.

My sense is that it is the rare case where the risk of otherwise discoverable misinformation should be on the buyers of securities rather than on the sellers; hence, a duty of reasonable effort to discover the truth should be presumed as a default. This is, in essence, what the law of negligent misrepresentation does at the level of state law, and it makes sense to extend this duty to selling intermediaries like brokers assisting in the private sale. ${ }^{121}$ Continuing with the state-law

116. 513 U.S. 561 (1995).

117. For a good, albeit critical, discussion of Gustafson and the events leading to it, see Stephen Bainbridge, Securities Act Section 12(2) After the Gustafson Debacle, 50 Bus. LAW. 1231 (1995).

118. See id.; see also Edmund Kitch, Gustafson v. Alloyd Corp.: An Opinion that Did Not Write, 1995 SUP. CT. REV. 99, 121.

119. For a more supportive view of the Gustafson result as applied to exempt offerings, see Peter Letsou, The Scope of Section 12(2) of the Securities Act of 1933: A Legal and Economic Analysis, 45 EMORY L.J. 95 (1996); see also Palmiter, supra note 18.

120. See In re Prudential Sec., Inc., [1993 Transfer Binder] Fed. Sec. L. Rep. (CCH) II 85, 238 (Oct. 21, 1993) (deciding enforcement action against seller of high risk limited partnership interests).

121. Under the Supreme Court's opinion in Pinter v. Dahl, 486 U.S. 622, 646 (1988), the term "seller" in Section 12(a) (applying equally, according to the courts, to both subsections (1) and (2)) extends to those who solicit on behalf of the actual seller. 
analogy, however, I would allow a waiver of this duty, if and when explicitly contracted for by the parties. Also as at common law, the standards for waiver should be fairly strict: Boilerplate waivers in mass-produced disclosure documents should not count. To this extent, at least, Gustafson should be overturned.

\section{$\mathrm{V}$ \\ CONCLUSION}

There can be no successful reform of the system of capital-raising regulation in the United States without rethinking the liability regime. To be sure, this is a difficult task: A strict system of securities fraud liability under the Securities Act has been a signature feature of American securities regulation since the 1930s, and questioning it can easily start the process of unraveling the whole set of assumptions under the 1933 Act. In this sense, it is similar to insider trading regulation, a core element of the identity of our system of regulation. ${ }^{122}$ Notwithstanding my strong commitment to aggressive regulation generally, reform of the sort outlined here is long overdue and can readily be accomplished in a way that does not unnecessarily compromise investor protection.

122. See Donald C. Langevoort, Rereading Cady, Roberts: The Ideology and Practice of Insider Trading Regulation, 99 COLUM. L. REV. 1319, 1328-31 (1999). 